\section{Flowering and Fruiting Patterns of Primocane-fruiting Blackberries}

\author{
Ellen Thompson ${ }^{1}$ and Bernadine C. Strik ${ }^{2,5}$ \\ Department of Horticulture, Oregon State University, 4017 ALS, Corvallis, \\ OR 97331
}

\author{
John R. Clark ${ }^{3}$ \\ Department of Horticulture, University of Arkansas, Plant Science 316, \\ Fayetteville, AR 72701
}

Chad E. Finn ${ }^{4}$

U.S. Department of Agriculture, Agricultural Research Service, Horticultural Crops Research Laboratory, 3420 NW Orchard Avenue, Corvallis, OR 97330

Additional index words. Rubus, 'Prime-Jan', 'Prime-Jim', bloom pattern

\begin{abstract}
The flowering morphology of the erect, thorny, primocane-fruiting blackberry (Rubus L. subgenus Rubus, Watson) cultivars 'Prime-Jan' and 'Prime-Jim' were studied in 2005 and 2006 in Aurora, OR. Primocanes that were "soft-tipped" in early summer to $1 \mathrm{~m}$ were compared with untipped primocanes. In both years, soft-tipped primocanes developed two- to threefold more branches and almost twice the number of flowers as untipped canes. 'Prime-Jan' and 'Prime-Jim' began blooming on the branches of softtipped canes in mid-July, whereas untipped primocanes began to bloom in late July in 2005 and 2006. Within a primocane inflorescence, the terminal or distal flower was always the first to open followed by terminal flowers from axes located on the basal portion of the inflorescence. Flowers then opened acropetally within the inflorescence, with the exception of the most basal flower, which was typically the last to open. The blooming pattern within an inflorescence was similar for soft-tipped and untipped primocanes. Days from anthesis to black fruit for soft-tipped and untipped primocanes averaged 45 to $51 \mathrm{~d}$ in both years, depending on cultivar.
\end{abstract}

The first primocane-fruiting blackberries, 'Prime-Jan' and 'Prime-Jim', were released in 2004 (Clark et al., 2005). This type of erect blackberry produces flowers and fruit on the first-year cane, the primocane, in addition to the second-year cane, the floricane. Primocane-fruiting blackberries may offer opportunities for season extension and off-season fruit production in both northern and southern hemispheres, particularly in mild climates. However, field observations have revealed that erect primocane-fruiting morphology is different from that of erect floricane-fruiting blackberry and primocane-fruiting raspberry (B. Strik, personal observation). Bloom pattern within an inflorescence and range in fruit maturity for semierect blackberries has been reported (Takeda, 1987). Fruiting lateral characteristics such as fruitfulness and node position have been described in red raspberry (Dale, 1979; Dale and Topham, 1980). Pro-

Received for publication 6 Feb. 2007. Accepted for publication 23 Mar. 2007.

We thank Gil Buller for assistance in data collection. From the M.S. thesis of E. Thompson.

${ }^{1}$ Graduate Research Assistant.

${ }^{2}$ Professor and Berry Research Leader, NWREC. ${ }^{3}$ Professor.

${ }^{4}$ Research Geneticist.

${ }^{5}$ To whom reprint requests should be addressed; e-mail strikb@hort.oregonstate.edu on flowering and fruit ripening patterns of primocanes.

\section{Materials and Methods}

In June 2003, tissue-cultured plugs of 'Prime-Jan' and 'Prime-Jim' were established at the North Willamette Research and Extension Center (NWREC), Aurora, OR; U.S. Dept. of Agriculture (USDA) hardiness zone 8; elevation $46 \mathrm{~m}$ above sea level; average last freeze date 17 Apr.; average first freeze date 25 Oct.; the weather records for this site can be viewed at Anonymous (2005-2006). The soil type was Quatama loam (fine-loamy, mixed, mesic Aqualtic Haploxeralfs). Plants were spaced $0.6 \mathrm{~m}$ in the row with $3 \mathrm{~m}$ between rows. Five-plant plots were $3 \mathrm{~m}$ long with $3 \mathrm{~m}$ separating plots. The field was drip-irrigated $(3.8 \mathrm{~L} / \mathrm{hr}$ emitters at $0.6-\mathrm{m}$ spacing) as required, typically $60 \mathrm{~min} / \mathrm{d}(7.6 \mathrm{~L} / \mathrm{d})$ from June through September. Plots were fertilized with $55 \mathrm{~kg} \cdot \mathrm{ha}^{-1}$ of $\mathrm{N}, 15 \mathrm{~kg} \cdot \mathrm{ha}^{-1}$ of $\mathrm{P}$, and $55 \mathrm{~kg} \cdot \mathrm{ha}^{-1}$ of $\mathrm{K}$ each spring and an additional $28 \mathrm{~kg} \cdot \mathrm{ha}^{-1}$ of $\mathrm{N}$ at primocane bloom. Weeds were controlled by use of preemergent herbicides and mechanical methods.

In early Aug. 2005 and 2006, three and six primocanes, respectively, of 'Prime-Jan' and 'Prime-Jim' under two cane management treatments were randomly chosen and flagged for observation: 1) primocanes "softtipped" (upper 2 to $5 \mathrm{~cm}$ removed) at $1 \mathrm{~m}$ and 2) untipped primocanes (control). In treatment 1 , primocanes were soft-tipped to $1 \mathrm{~m}$ on several occasions during the growing season, from 15 to 29 June 2005 and from 7 to 26 June 2006, to appropriately tip the various flushes of cane growth. In both treatments, only a primocane crop was harvested. For each cultivar, order of bloom within an inflorescence, as described by Takeda (1987), number of flowers and berries per inflorescence, and days from terminal bloom anthesis to shiny black fruit (Perkins-Veazie et al., 1996) for fruiting structures were recorded. Branches on flagged canes for both treatments and cultivars were labeled and photographed daily to observe bloom pattern. Number of branches, node position of branches, branch length, total node number of branches and main cane, number of fruiting nodes, number of flowers, subsequent ripening among branches within a cane, and days from terminal bloom anthesis to shiny black fruit for each branch were recorded for each treatment and cultivar. The data were analyzed, when appropriate, using PROC GLM (version 9.1; SAS Institute, Cary, NC).

\section{Results and Discussion}

In both years, primocane emergence for 'Prime-Jan' and 'Prime-Jim' began in early February. Primocanes emerged from adventitious buds on roots and the crown. On average, untipped primocanes of 'PrimeJan' and 'Prime-Jim' developed two lateral branches in 2005 and less than one per cane in 2006. When present, branches were always 
located on nodes near the base of the cane. Untipped canes maintained apical dominance and were determinate in growth. Thus, fruiting sites were always found at the tips of the main cane and branches. Untipped primocanes of 'Prime-Jan' and 'Prime-Jim' averaged 1.8 and $2.0 \mathrm{~m}$ in length in 2005 and 2.1 and $2.2 \mathrm{~m}$ in 2006, respectively. Average branch length for untipped canes was $1.3 \mathrm{~m}$ for 'Prime-Jan' and $1.0 \mathrm{~m}$ for 'Prime-Jim' in 2005. In 2006, average branch length for untipped 'Prime-Jan' and 'Prime-Jim' was $0.45 \mathrm{~m}$ and $0.68 \mathrm{~m}$, respectively. Untipped primocanes (main cane + any branches) for 'Prime-Jan' averaged 95 total nodes in 2005; however, only $27 \%$ of the nodes were fruitful (Table 1). In 'Prime-Jim', total nodes averaged 98 with $19 \%$ of those being fruitful. In contrast, untipped 'Prime-Jan' and 'PrimeJim' had fewer total nodes in 2006, 67 and 59, yet a higher percentage was fruitful than in $2005,36 \%$ and $25 \%$, respectively (Table 1 ).

Soft-tipped canes developed multiple lateral branches just below the site of tipping resulting in an average of five branches per cane for both cultivars in 2005 and four branches in 2006. In both years, the first three nodes below the site of tipping always developed a lateral branch. Additional branches developed sporadically down the 1-m long cane. The main cane on soft-tipped primocanes did not develop fruiting sites, because only lateral branches ended in inflorescences. In 2005, average branch length for softtipped canes was $0.63 \mathrm{~m}$ and $0.52 \mathrm{~m}$ for 'Prime-Jan' and 'Prime-Jim', respectively. Similar to untipped canes, branches were also shorter on soft-tipped canes in 2006, averaging $0.46 \mathrm{~m}$ and $0.49 \mathrm{~m}$ for 'Prime-Jan' and 'Prime-Jim', respectively. In both cultivars and years, soft-tipping produced significantly more fruitful nodes. In 2005, 'Prime-Jan' and 'Prime-Jim' had 89 and 67 nodes on branches with $55 \%$ and $54 \%$ being fruitful, respectively (Table 1). Like with untipped canes, there were fewer total nodes on soft-tipped canes in 2006 than in 2005. 'Prime-Jan' and
'Prime-Jim' produced 70 and 64 total nodes, of which $60 \%$ and $63 \%$ were fruitful, respectively (Table 1). The greatest effect of primocane management technique was on the location of inflorescences and number of flowers per cane. Untipped canes and lateral branches on untipped and soft-tipped canes developed flowers on a panicle-like cyme (Judd et al., 1999), which ended in an inflorescence and developed lower secondary axial fruiting laterals. Bloom pattern for terminal inflorescences and lower fruiting laterals on untipped and soft-tipped primocanes was similar for cultivars and years. Below the terminal inflorescence on untipped and soft-tipped primocanes, four to seven secondary fruiting laterals generally developed.

In untipped canes, $A_{1}$ refers to the main cane or branch (Fig. 1). In soft-tipped canes, $A_{1}$ refers only to branches (Fig. 1). The terminal flower on the main cane or branch, located on $\mathrm{A}_{1}$, was always the first to open in both cultivars (Fig. 1, "1"). This was followed by a terminal flower on a lower fruiting lateral located on an $\mathrm{A}_{2}$ axis near the basal portion of the inflorescence, similar to semierect blackberry (Takeda, 1987). However, the most basal $\mathrm{A}_{2}$ axis in this study was often the last to bloom (Fig. 1, "8"). On soft-tipped and untipped primocane inflorescences, it was common to have $\mathrm{A}_{3}$ axes, and occasionally $\mathrm{A}_{4}$ axes. Blooming of $\mathrm{A}_{3}$ axes would begin simultaneously with the last opening of the flower on the upper-most $A_{2}$ axis, which was generally the flower located directly below the terminal flower on the $A_{1}$ axis. The flower on the most basal $\mathrm{A}_{2}$ axis also opened at the same time, or just after, the opening of the most apical $\mathrm{A}_{2}$ axis flower. Most apical and basal $\mathrm{A}_{2}$ axes consisted of a single flower. The time between the opening of the $A_{1}$ terminal flower and the first $A_{2}$ flower was typically 1 to $3 \mathrm{~d}$ for both cultivars and did not vary with year. Once the first $\mathrm{A}_{2}$ axis began to bloom, other $\mathrm{A}_{2}$ axes followed acropetally, opening at a constant rate of two to three flowers per day. For $\mathrm{A}_{2}$ axes with multiple $\mathrm{A}_{3}$ flowers, a 3- to 4-d period between $\mathrm{A}_{3}$ flower openings was typical. When present, $\mathrm{A}_{4}$ flowers opened last.

The time from first to last open flower $\left(\mathrm{A}_{1}\right.$ to $\mathrm{A}_{4}$, respectively) within an inflorescence averaged $17 \mathrm{~d}$ for both cultivars and treatments in 2005 and 2006. In 2005, untipped canes averaged 49 flowers per cane and were unaffected by cultivar (Table 1). In 2006, untipped canes of 'Prime-Jan' averaged 68 flowers per cane, whereas 'Prime-Jim' averaged 59 (Table 1). Although 'Prime-Jan' and 'Prime-Jim' had similar numbers of total flowers per cane, untipped primocanes of 'Prime-Jim' had fewer fruiting nodes than those of 'Prime-Jan' in 2005 and 2006 (Table 1). This may imply that 'Prime-Jim' developed more $\mathrm{A}_{3}$ and $\mathrm{A}_{4}$ axes within an inflorescence.

On soft-tipped canes, the most apical lateral branches bloomed within $1 \mathrm{~d}$ of each other in both years. Usually, the most basal of the three branches was the first to have the terminal flower on $A_{1}$ fully open, followed by the branches above it, located at nodes 1 and 2 . The number of days between branch three $A_{1}$ and branch four $A_{1}$ bloom ranged from 2 to $6 \mathrm{~d}$ for 'Prime-Jim' and 'Prime-Jan', respectively. Most of the canes studied in 2005 had five branches and the number of days to bloom from branch one $A_{1}$ to branch five $A_{1}$ ranged from 18 to $21 \mathrm{~d}$ for 'PrimeJan' and 'Prime-Jim', respectively. In 2006, primocanes with five branches had a similar bloom pattern as observed in 2005. Canes with fewer than five branches had a shorter period between the bloom of $A_{1}$ (Fig. 1) on branch one to $A_{1}$ bloom on the most basipetal branch. In general, branch bloom pattern among soft-tipped canes was similar for both cultivars in 2005 and 2006. Soft-tipped canes had $31 \%$ to $70 \%$ more flowers than untipped primocanes, depending on cultivar and year (Table 1).

Once the terminal flowers on upper branches opened, bloom rate and pattern were as described for both cultivars. Although $\mathrm{A}_{1}$

Table 1. The effect of soft-tipping primocanes on the flowering and fruiting pattern of primocanes of 'Prime-Jan' and 'Prime-Jim' in 2005 ( $\mathrm{n}=3$ ) and 2006 $(\mathrm{n}=6)($ mean $\pm \mathrm{SE})$.

\begin{tabular}{|c|c|c|c|c|c|c|c|c|}
\hline \multirow[b]{2}{*}{ Cane management } & \multicolumn{3}{|c|}{ Prime-Jan } & \multirow[b]{2}{*}{ Fruit set $(\%)$} & \multicolumn{3}{|c|}{ Prime-Jim } & \multirow[b]{2}{*}{$\begin{array}{c}\text { Fruit } \\
\text { set }(\%)\end{array}$} \\
\hline & $\begin{array}{c}\text { Total } \\
\text { nodes/cane }\end{array}$ & $\begin{array}{c}\text { Fruiting } \\
\text { nodes/cane }\end{array}$ & Flowers/cane ${ }^{\mathrm{x}}$ & & $\begin{array}{c}\text { Total } \\
\text { nodes/cane }\end{array}$ & $\begin{array}{c}\text { Fruiting } \\
\text { nodes/cane }\end{array}$ & Flowers/cane ${ }^{\mathrm{x}}$ & \\
\hline \multicolumn{9}{|l|}{2005} \\
\hline Untipped primocane & $95 \pm 48$ & $26 \pm 15$ & $50 \pm 24$ & $90 \pm 2$ & $98 \pm 51$ & $19 \pm 6$ & $48 \pm 17$ & $88 \pm 4$ \\
\hline Soft-tipped primocane ${ }^{\mathrm{w}}$ & $89 \pm 40$ & $49 \pm 17$ & $74 \pm 31$ & $83 \pm 1$ & $67 \pm 6$ & $36 \pm 4$ & $82 \pm 6$ & $87 \pm 0$ \\
\hline \multicolumn{9}{|l|}{2006} \\
\hline Untipped primocane & $67 \pm 13$ & $24 \pm 6$ & $68 \pm 17$ & $85 \pm 3$ & $59 \pm 5$ & $15 \pm 1$ & $59 \pm 12$ & $94 \pm 1$ \\
\hline Soft-tipped primocane & $70 \pm 13$ & $42 \pm 6$ & $101 \pm 12$ & $84 \pm 3$ & $64 \pm 14$ & $40 \pm 6$ & $77 \pm 19$ & $94 \pm 2$ \\
\hline \multicolumn{9}{|l|}{ Significance $^{\mathrm{v}}$} \\
\hline Cultivar & NS & NS & NS & $*$ & - & - & - & - \\
\hline Year & NS & NS & NS & NS & - & - & - & - \\
\hline Tipping & NS & $*$ & NS & NS & - & - & - & - \\
\hline Cult $\times$ year & NS & NS & NS & $*$ & 一 & - & - & - \\
\hline
\end{tabular}

${ }^{\mathrm{z}}$ Average total number of nodes/cane (including any branches).

${ }^{\mathrm{y}}$ Average total number of nodes/cane (including any branches) that produced an inflorescence or flowering lateral.

${ }^{\mathrm{x}}$ Average total flowers/cane (including any branches).

wTotals for soft-tipped canes include only branches, not the main cane.

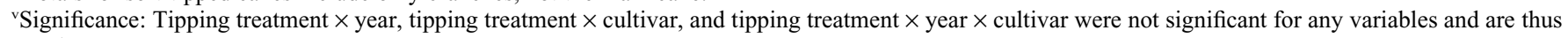
not shown.

Ns, ${ }^{* * * *}$ Nonsignificant or significant at $P<0.05$ or 0.01 , respectively. 


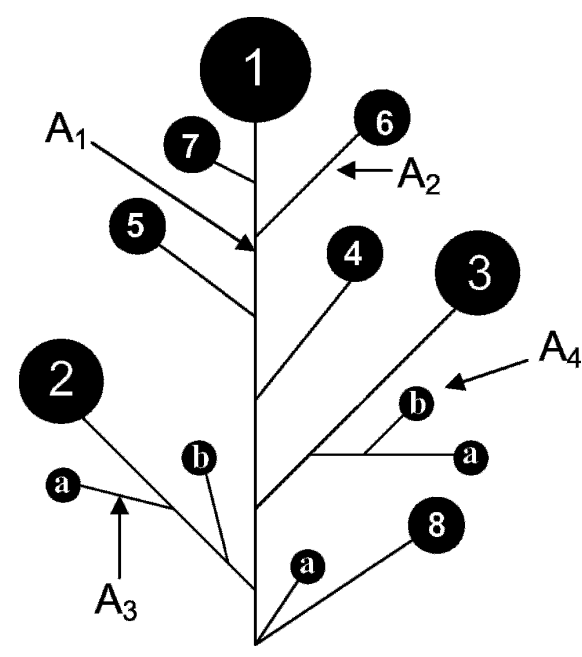

Fig. 1. Structure of bloom pattern of an inflorescence on soft-tipped and untipped primocanes. Order of bloom is designated " 1 " through " 8. ." Numbered flowers preceded lettered flowers.

flowers on the third branch tended to open earlier than the upper two branches, $A_{1}$ bloom pattern for the remaining lower branches was basipetal. In both cultivars and years, a few basal branches remained vegetative, whereas others were still blooming or fruiting when observations were stopped on 10 Oct. 2005 and 29 Oct. 2006 as a result of adverse weather.

In untipped primocanes, more variation occurred for branch $\mathrm{A}_{1}$ bloom pattern in both cultivars. In general, the $A_{1}$ flower on the main cane opened before $A_{1}$ flowers on basal lateral branches, when present. However, one primocane of 'Prime-Jan' in 2005 had black fruit on all branches before the $A_{1}$ flower on the main cane opened. More typically on both cultivars, however, untipped primocanes with branches had open basal branch $\mathrm{A}_{1}$ flowers 18 to $21 \mathrm{~d}$ after the $A_{1}$ flower on the main cane had opened, similar to basal branches on tipped canes. However, one basal branch on an untipped 'Prime-Jim' cane in 2006 developed late in the season and subsequently bloomed $57 \mathrm{~d}$ after the $\mathrm{A}_{1}$ flower on the main cane had opened. Like with soft-tipped primocanes, a few basal branches on untipped primocanes remained vegetative at the end of the growing season in both years.

Days from anthesis to shiny black fruit for soft-tipped and untipped primocanes was similar in both years, averaging 51 and $45 \mathrm{~d}$ for 'Prime-Jan' and 'Prime-Jim', respectively. Percent fruit set tended to be higher on untipped canes in 2005 in 'Prime-Jan' but not in 'Prime-Jim'. 'Prime-Jan' had a significantly lower percent fruit set on soft-tipped canes than 'Prime-Jim' in both years.

In conclusion, soft-tipping primocanes to $1 \mathrm{~m}$ encouraged branching and thereby significantly increased the number of fruiting nodes per cane compared with untipped primocanes. Furthermore, branching was more predictable in soft-tipped primocanes, particularly below the site of tipping, resulting in more uniformity of fruit ripening. Untipped primocanes consistently reached $2 \mathrm{~m}$ in length, making fruit difficult for pickers to reach and increased the risk of cane breakage. In both years, soft-tipped and untipped primocanes produced basal lateral branches that remained vegetative. This may imply that tipping branches, and thereby removing apical dominance, may encourage termination in an inflorescence and perhaps further increase the number of flowers per branch.

\section{Literature Cited}

Anonymous. 2005-2006. U.S. Department of the Interior, Bureau of Reclamation, Boise, ID. Agrimet Weather Station web site. 13 Nov. 2006. $<$ http://www.usbr.gov/pn/agrimet/wxdata. $\mathrm{html}>$.

Clark, J.R., J.N. Moore, J. Lopez-Medina, C. Finn, and P. Perkins-Veazie. 2005. 'Prime-Jan' ('APF-8') and 'Prime-Jim' ('APF-12') primocane-fruiting blackberries. HortScience 40 852-855.

Dale, A. 1979. Varietal differences in the relationships between some characteristics of red raspberry fruiting laterals and their position on the cane. J. Hort. Sci. 54:257-265.

Dale, A. and P.B. Topham. 1980. Fruiting structure of the red raspberry: Multivariate analysis of lateral characteristics. J. Hort. Sci. 55: 397-408.

Drake, C. and J.R. Clark. 2003. Effects of pruning and cropping on field-grown primocane-fruiting blackberries. HortScience 38:260-262.

Judd, W.S., C.S. Campbell, E.A. Kellog, and P.F. Stevens. 1999. Plant Systematics: A phylogenetic approach. Sinauer Associates Inc., Sunderland, MA.

Perkins-Veazie, P., J.K. Collins, and J.R. Clark. 1996. Cultivar and maturity affect postharvest quality of fruit from erect blackberries. HortScience 31:258-261.

Strik, B., J.R. Clark, C. Finn, and G. Buller. 2007. Management of primocane-fruiting blackberry to maximize yield and extend the fruiting season. Acta Hort. in press.

Takeda, F. 1987. Some factors associated with fruit maturity range in cultivars of the semi-erect, tetraploid thornless blackberry. HortScience $22: 405-408$ 